\title{
Talent Management in Mediating Competencies and Motivation to Improve Employee's Engagement
}

Submitted $22 / 2 / 18,1^{\text {st }}$ revision $10 / 4 / 18,2^{\text {nd }}$ revision $17 / 9 / 18,3^{\text {rd }}$ revision $28 / 11 / 18$ accepted 3/2/19

\section{Lenny Ch Nawangsari ${ }^{1}$, Ahmad Hidayat Sutawidjaya ${ }^{2}$}

\begin{abstract}
:
This research aims to analyze the influence of the competence, motivation and talent management towards Employee Engagement in Small Medium Enterprise (SME) in the Tour \& Travel sector in Malang by using a quantitative approach and adopting the survey method.

The sample used for this research consisted of 101 people. Data were collected using a questionnaire with a five point Likert scale. The data analysis technique used is a Generalized Structured Component Analysis.

The results of this research show that: 1) Competence directly and positively influences Employee Engagement, 2) Motivation directly and positively influences Employee Engagement, 3) Talent Management directly and positively influences Employee Engagement, 4) Competence directly and positively influences Talent management, 5) Motivation directly and positively influences Talent Management, 6) Competence directly influences Employee Engagement through the mediation of Talent Management and 7) Motivation directly influences Employee Engagement through the mediation of Talent Management.
\end{abstract}

Keywords: Competence, Motivation, Talent Management, Employee Engagement, SME Tour \& Travel Malang.

${ }^{1}$ Corresponding author, Magister Management, Mercu Buana University, Jakarta, Indonesia lenny.nawangsari@gmail.com

${ }^{2}$ Doctoral Management, Mercu Buana University, Jakarta, Indonesia suta.phd@gmail.com 


\section{Introduction}

The business world is currently facing pretty heavy challenges relating to VUCA (Volatility, Uncertainty, Complexity \& Ambiguity). Given that companies operate in an environment which is uncertain and complex, they need to improve thier strategy so as to remain competitive in the business world. In addition, companies are also expected to create added value for competitive advantage, including in the field of human resources. The same condition is also experienced by small and medium enterprises (SMEs). To improve the competitiveness of SMEs, a business must also pay attention to the management of human resources (HR). Good management of human resources will increase productivity and profitability.

The tourism business is a very interesting area for study given the tourism potential which the region Indonesia has. The business related to tourism flourished in several areas lately including in the city of Malang. From data and observations on some SMEs in the Tour \& Travel sector, one finds problems related to turnover since some SMEs lack talented resources to manage their business. Most talented human resources prefer joining bigger companies. Therefore, SMEs need to develop a human resource management strategy so that they can find, develop and retain talented people to add value to the business. Some previous research asserts that Talent Management is very important in business organization (Farndale et al., 2014; Scullion and Colings, 2010; Krishnan and Scullion, 2017). Talent management is also a very important asset in business competitiveness (Krishnan and Scullion, 2017). Talent management in small and medium enterprises (SMEs) is very diverse e.g., in the model proposed by Baublyte (2010) he argues that formal talent management procedures are not required due to a high level of flexibility in its business. Facing globalization, businesses also need qualified talent to focus on business sustainability (Lance, 2011; Scullion, 2011; Akram, 2014). Through good talent management SMEs can be expected to improve the attachment of employees to same SMEs.

Based on previous research, there are several factors that affect Employee Engagement, like organizational culture, motivation, job satisfaction, leadership, talent management, innovation, competency, work environment, and compensation. The results obtained by research so far is that competence, motivation and Talent Management are strong factors which affect Employee Engagement. With regards to such phenomena above, researchers wanted to see whether talent management could mediate with competence and motivation to improve Employee Engagement in SME Tour \& Travel.

\section{Literature review}

Competence, according to Le Deist et al., (2006) is the same as ability, that is, the concept of bringing together the knowledge and skills on various important elements. Dimensions and indicators of competence are divided into three, namely, 
the cognitive dimension, the social dimension and the functional dimension. The relationship between the three dimensions of competency is combined in the framework of comprehensive understanding. The three dimensions have a value which is universal and is explained as the depth of knowledge.

The motivation of working according to George and Jones (2012), is defined as an encouragement to someone to psychologically determine the direction of his behaviour (direction of behavior). So, motivation can be defined as the morale of the employees who work to achieve a particular goal. McClelland (1961), stated that Achievement Motivation Theory focuses on three human needs which are: 1) the need for achievement (need of achievement), namely the desire to learn and excel in life, 2) the need for power (need for power), namely the need to lead and influence others, and 3) the need for affiliation (need of affiliation), namely the need to interact with others.

Talent Management according to Lockwood (2006) is the application of the integrated system or strategy that is designed to increase productivity in the workplace by developing a better process to attract, develop, retain, and utilizing the people with the skills and abilities needed to meet the business needs of today and the future. Meanwhile, according to The Office of Talent Management and Organizational Development (2010), Talent Management is the order of organizational human resources processes that are designed to attract, develop, motivate, and retain workers who produce and are bound (engaged).

MacLeod \& Clarke (2009) state that the Employee engagement is a sense of emotional attachment with work and the organization, making the person motivated and able to give their best ability to help wth the success of real benefits for organizations and individuals. According to Gibbons (2006) and Thomas (2007) employee engagement consists of preparedness, readiness and pride.

Some earlier research relating to competence, motivation and talent management was conducted by Lara and Salas-Vallina (2017) focussing on the influence of competence towards Employee Engagement and its effect on Employee Competency Engagement in SME. Research related to the influence of Motivation towards Employee Engagement conducted by Clayton (2006) states that Motivation has an effect on Employee Engagement. Research on Talent Management towards Employee Engagement conducted by Bhatnagar (2007), Bano et al., 2011 and Sadeli (2012), all prove that Talent Management effects Employee Engagement. Sabuncu and Karacay (2016) conducted research related to competencies with talent management and Delfgaauw (2010) also conducted research on motivation and Talent management. Based on the study of the theory and previous research, then the hypothesis proposed are:

\section{Hypothesis 1: Competence directly and positively influences employee's} engagement. 
Hypothesis 2: Motivation directly and positively influences employee's engagement.

Hypothesis 3: Talent Management directly and positively influences employee'e engagement.

Hypothesis 4: Competence directly and positively influences talent management. Hypothesis 5: Motivation directly and positively influences talent management.

Hypothesis 6: Competence directly influences employee's engagement through the mediation of talent management.

Hypothesis 7: Motivation directly influences employee's engagement through the mediation of talent management.

\section{Research Methods}

This research uses a quantitative approach with survey method conducted on employees of SMEs in the Travel \& Tour sector in Malang city with total sample of 101 people. All variables in the study were measured using a five-point Likert scale.

\section{Results and Discussion}

The inferential statistical analysis method is used to test the empirical model and hypothesis in this research. In this study, the Generalized Structured Component Analysis (GSCA) developed by Hwang and Takane (2004) was implemented. The analysis steps are as follows:

\subsection{Measurement Model Testing}

There are 3 (three) criteria to assess in the measurement model:

\section{a. Convergent validity:}

Convergent validity test describes the correlation measure between the reflective indicator score and the latent variable score. For this, loading $\geq 0.40$ is considered valid. Test Results on Convergent validity can be seen in Table 1.

Table 1. Result Test Validity Convergen

\begin{tabular}{lllll}
\hline No & Variables & Indicators & Loading & Note \\
\hline 1 & Competences & $(\mathrm{X} 1.1)$ & 0,843 & Valid \\
& & $(\mathrm{X} 1.2)$ & 0,876 & Valid \\
\multirow{2}{*}{2} & \multirow{2}{*}{ Motivation } & $(\mathrm{X} 1.3)$ & 0,877 & Valid \\
& & $(\mathrm{X} 2.1)$ & 0,825 & Valid \\
& & $(\mathrm{X} 2.2)$ & 0,861 & Valid \\
3 & \multirow{2}{*}{ Talent Management } & $(\mathrm{X} 2.3)$ & 0,757 & Valid \\
& & $(\mathrm{Y} 1.1)$ & 0,905 & Valid \\
\multirow{2}{*}{4} & Employee Engagement & $(\mathrm{Y} 1.2)$ & 0,847 & Valid \\
& & $(\mathrm{Y} 2.1)$ & 0,851 & Valid \\
& & $(\mathrm{Y} 2.2)$ & 0,864 & Valid \\
\hline
\end{tabular}




(Y2.3) $\quad 0,853 \quad$ Valid

Table describes the estimated value at loading in each indicator variable which is $\geq$ 0.40 , so it can be concluded that the variable is valid.

\section{b. Discriminant validity:}

In testing the discriminant validity of an instrument, it is said that if $\sqrt{A V E}$ is greater than the correlation coefficient of variables, then it is valid. Discriminant validity test results can be seen in Table 2 below.

Table 2. Test Result Validity Discriminant

\begin{tabular}{lllllll}
\hline & AVE & $\begin{array}{l}\text { Compe- } \\
\text { tences } \\
(\mathrm{X} 1)\end{array}$ & $\begin{array}{l}\text { Motivation( } \\
\text { X2) }\end{array}$ & $\begin{array}{l}\text { Talent } \\
\text { Manage-ment } \\
(\text { Y1) }\end{array}$ & $\begin{array}{l}\text { Employ } \\
\text { ee } \\
\text { Engage } \\
\text { ment } \\
(\text { Y2) }\end{array}$ & Note \\
\hline $\begin{array}{l}\text { Competences } \\
\text { (X1) }\end{array}$ & 0,749 & 1 & 0,709 & 0,448 & 0,534 & Valid \\
$\begin{array}{l}\text { Motivation } \\
(X 2)\end{array}$ & 0,665 & 0,609 & 1 & 0,425 & 0,538 & Valid \\
$\begin{array}{l}\text { Talent } \\
\begin{array}{l}\text { Management } \\
(Y 1)\end{array}\end{array}$ & 0,753 & 0,448 & 0,425 & 1 & 0,632 & Valid \\
$\begin{array}{l}\text { Employee } \\
\text { Engagement } \\
(Y 2)\end{array}$ & 0,716 & 0,534 & 0,538 & 0,632 & 1 & Valid \\
\hline
\end{tabular}

Table 2 explains that in all research variables, $\sqrt{ }$ AVE is greater than the correlation coefficient between variables compared with other variables. Thus, the research instrument is valid.

\section{c. Internal Consistensy:}

In testing the Internal Consistency Reliability of an instrument, the researcher needs to obtain an alpha value above 0.60 . The results of the research reliability test can be seen in Table 3.

Table 3. Reliability Test Results of Research Instruments

\begin{tabular}{lll}
\hline Variables & Alpha & Note \\
\hline Competences (X1) & 0,832 & Reliabel \\
Motivation (X2) & 0,741 & Reliabel \\
Talent Management (Y1) & 0,834 & Reliabel \\
Employee Engagement (Y2) & 0,802 & Reliabel \\
\hline
\end{tabular}

Table 3 shows that all the variables produce alpha values above 0.60 , thus, it can be concluded that the research instruments have a good internal consistency. 


\subsection{Evaluation Goodness-of-fit Model Structure and Model Overall}

Table 4 shows the analysis result with GSCA method.

Table 4. Evaluation Goodness-of-fit Model Structur and Model Overall Model in GSCA

\begin{tabular}{ll}
\hline MODEL FIT & \\
\hline FIT & 0,586 \\
AFIT & 0,581 \\
GFI & 0,980 \\
SRMR & 0,199 \\
NPAR & 29 \\
\hline
\end{tabular}

The results of the above analysis are enough to meet the requirements of Goodnessof-Fit.

\section{$5 \quad$ Hypothesis testing}

\subsection{Hypothesis Testing and Coefficient of Direct Effect Line}

Testing hypothesis and path coefficient show a direct influence between competence, motivation, talent management and Employee Engagement. The direct impact test can be seen from the value of path coefficient and critical point $(\mathrm{CR} *)$ which is significant at $\alpha=0,05$. The test results of direct influence between the variables in detail can be seen in Table 5 .

Table 5. Coefficient Direct Effect and Hypothesis Testing

\begin{tabular}{|c|c|c|c|c|}
\hline No & Direct Correlation & $\begin{array}{l}\text { Path } \\
\text { Coef }\end{array}$ & $\begin{array}{l}\text { C.R. } \\
\text { (Uji t) }\end{array}$ & Conclusion \\
\hline 1 & $\begin{array}{lll}\text { Competences (X1) } & \rightarrow & \text { Employee } \\
\text { Engagement (Y2) } & & \\
\end{array}$ & 0,170 & $2,67 *$ & Significant \\
\hline 2 & $\begin{array}{llll}\text { Motivation } \quad(\mathrm{X} 2) & \rightarrow & \text { Employee } \\
\text { Engagement (Y2) } & & \\
\end{array}$ & 0,222 & $2,55^{*}$ & Significant \\
\hline 3 & $\begin{array}{l}\text { Talent Management (Y1) } \rightarrow \text { Employee } \\
\text { Engagement (Y2) }\end{array}$ & 0,462 & $7,36^{*}$ & Significant \\
\hline 4 & $\begin{array}{l}\text { Competences (X1) (X1) } \rightarrow \text { Talent } \\
\text { Management (Y1) }\end{array}$ & 0,295 & $2,67 *$ & Significant \\
\hline 5 & $\begin{array}{l}\text { Motivation }(\mathrm{X} 2) \rightarrow \text { Talent Management } \\
(\mathrm{Y} 1)\end{array}$ & 0,216 & $0,105^{*}$ & Significant \\
\hline
\end{tabular}

Note: $*=$ significant to $\alpha=0,05$

Based on the above analysis, the results obtained for Hypothesis Testing Research are as follows:

H1: Competence directly and positively influences employee's engagement.

The result of analysis shows that the coefficient value of direct influence of Competence to Employee Engagement is 0,170 with critical point 2,67, meaning that 
there is significant influence of Competence to Employee Engagement. This indicates that hypothesis 1 which states "Competence directly and positively influences Employee Engagement" is accepted. The results of this analysis indicate with the increase in Employee Competence can increase Employee Engagement.

H2: Motivation directly and positively influences employee's engagement.

The results of the analysis state the acquisition coefficient value of direct influence motivation to employee's engagement of 0.222 with a critical point 2.55 , meaning that there is a significant influence motivation on employee's engagement. These results indicate that hypothesis 2 which states "Motivation directly and positively influences employee's engagement" is accepted. The results of this analysis indicate that an increase in motivation will affect the increase in employee engagement.

H3: Talent Management directly and positively influences employee's engagement.

The result of the analysis shows that the coefficient of talent management's direct effect to employee's engagement is 0.462 with critical point 7.36 , meaning that there is significant talent management influence employee's engagement. The result of the analysis shows empirically that hypothesis 3 which states "Talent Management directly and positively influences employee's engagement" is accepted. This indicates that good talent management within the organization will increase the employee's engagement.

\section{H4: Competence directly and positively influences talent management.}

The results of the analysis states that the obtained value of coefficient of the direct influence of competence to talent management is 0.295 with a critical point 2.67 , meaning there is a significant influence of competence on talent management. The results of the analysis indicate that hypothesis 4, which states "Competence directly and positively influences talent management" is accepted. The results of this analysis show that good employee competence can improve talent management within the company.

\section{H5: Motivation directly and positively influences talent management.}

The results of the analysis show that the obtained value of coefficient of the direct influence of motivation to talent management is of 0.216 with a critical point of 0.105 , meaning there is a significant influence of motivation on talent management. The results of this analysis state that hypothesis 5, stating "Motivation directly and positively influences talent management" is accepted. This indicates that good motivation can improve talent management in the company.

H6: Competence directly influences employee's engagement through the mediation of talent management. 
The result of analysis states that the obtained value of coefficient of the direct influence of competence to Talent management is 0,295 with a critical point of 2,67, meaning that there is a significant influence of competence to talent management. The obtained value of the coefficient of a direct influence of talent management to employee engagement is equal to 0,462 with a critical point 7,36 , meaning that there is a significant influence of talent management to employee's engagement. The results of the analysis also showed a significant influence of competence on the employee's engagement with an effective coefficient of 0.170 with a critical point of 2.67. It shows there is indirect influence between competence and employee's engagement through talent management. The results of the above analysis indicate that there is empirical evidence that Hypothesis 6, which states, "Competence directly influences employee's engagement through the mediation of talent management" is accepted. The result of this analysis shows that talent management mediates the relationship between competence and employee's engagement.

\section{H7: Motivation directly influences employee's engagement through the mediation of talent management.}

The result of the analysis shows that the value of the coefficient of a direct influence of motivation to talent management is equal to 0,216 with a critical point 1,05 , meaning there is a significant influence of motivation to talent management. The value of the coefficient of the direct influence of talent tanagement to employee's engagement is equal to 0,462 with a critical point 7,36 , meaning there is a significant influence of talent management to employee's engagement. The results of the analysis also show a significant influence of motivation to employee's engagement with an effective coefficient of 0.222 with a critical point 2.55 . The results of the above analysis indicate there is an indirect influence between motivation and employee's engagement through talent management. The results of the analysis indicate that there is empirical evidence that Hypothesis 7, stating "Motivation directly influences employee's engagement through the mediation of talent management" is accepted. This means that talent management mediates the relationship between motivation and employee's engagement.

\subsection{Examination of the coefficient path on the influence of mediation}

The results of the coefficient testing on mediation can be seen in Table 6 below:

Table 6. The coefficients the influence mediation

\begin{tabular}{|l|l|l|l|l|l|l|l|}
\hline $\mathbf{N}$ & Correlation & Mediation & \multicolumn{4}{|l|}{ Path coefficient } & \multirow{2}{*}{ Conclusion } \\
\cline { 4 - 7 } $\mathbf{0}$ & Variables & variable & $\mathbf{A}$ & $\mathbf{B}$ & $\mathbf{C}$ & $\mathbf{d}$ & \\
\hline 1 & Competences & Talent & 0,170 & 0,136 & 0,295 & 0,462 & Partial \\
& $(\mathrm{X} 1)$ & Management & $*$ & $*$ & $*$ & $*$ & Mediation \\
& Employee & (Y1) & & & & & \\
& $\begin{array}{l}\text { Engagement } \\
\text { (Y2) }\end{array}$ & & & & & & \\
\hline
\end{tabular}




\begin{tabular}{|l|l|l|l|l|l|l|l|}
\hline $\mathbf{N}$ & Correlation & Mediation & \multicolumn{4}{|l|}{ Path coefficient } & Conclusion \\
\cline { 4 - 7 } $\mathbf{0}$ & Variables & variable & A & B & C & d & \\
\hline 2 & Motivation(X2) & Talent & 0,222 & 0,099 & 0,216 & 0,462 & Partial \\
& $\begin{array}{l}\rightarrow \quad \text { Employee } \\
\text { Engagement } \\
\text { (Y2) }\end{array}$ & $\begin{array}{l}\text { Management } \\
(Y 1)\end{array}$ & $*$ & $*$ & $*$ & $*$ & Mediation \\
& & & & & & \\
\hline
\end{tabular}

Note: $*=$ Significant to $\alpha=0,05$.

Based on the above analysis, it is proved that talent management is a partially mediating variable in the relationship between competency and employee's engagement and in the relationship between motivation and employee's engagement.

\subsection{The analysis model}

Based on the analysis conducted above, one can observe a path model of influence as in Figure 1.

Figure 1. Model the analysis

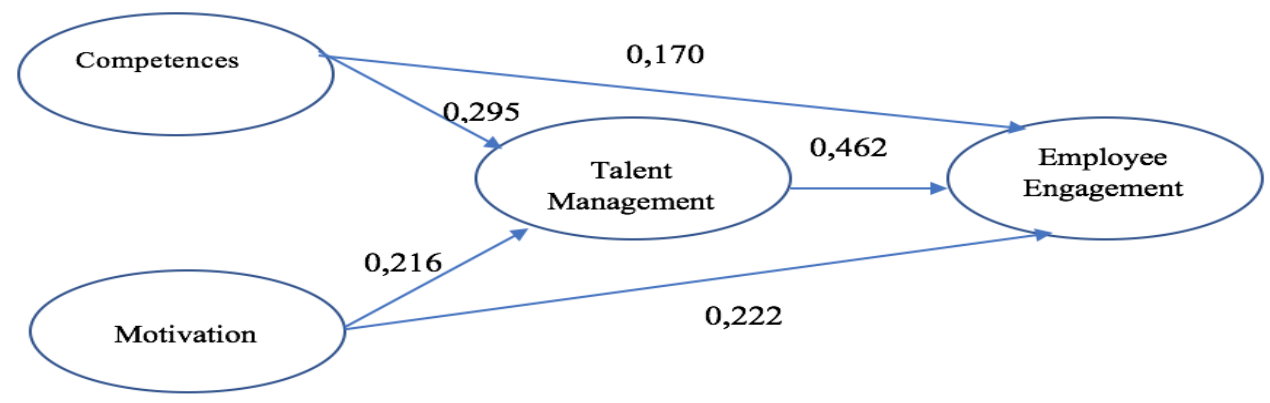

Figure 1 shows the existence of 5 direct influences, namely: 1) Competence has a significant effect on employee's engagement; 2) Motivation has a significant effect on employee's engagement; 3) Talent management has a significant effect on employee's engagement; 4) Competence has a significant effect on talent management, and 5) Motivation has a significant effect on talent management. Besides, there are two indirect influences: 1) Competence to employee's engagement through talent management and 2) Motivation to employee's engagement through talent management.

\subsection{Testing loading factors}

The loading factor assessment is used to find out the strongest indicator of the variable. The highest loading factor value shows the strongest variable indicator that is interpreted as an indicator with the dominant contribution to reflect the variables. The result of the mean value recapitulation and the loading factor of each indicator variable is shown in Table 7. 
Table 7. Recapitulation Estimate Loading

\begin{tabular}{|l|l|l|l|}
\hline Variable & Instruments & \multicolumn{1}{l|}{$\begin{array}{l}\text { Estimate } \\
\text { Loading }\end{array}$} \\
\hline Competences (X1) & Cognitive & $\mathrm{X} 1.1$ & 0,843 \\
\hline & Functional & $\mathrm{X} 1.2$ & 0,876 \\
\hline & Social & $\mathrm{X} 1.3$ & $\mathbf{0 , 8 7 7} *$ \\
\hline Motivation (X2) & The need for achievement & $\mathrm{X} 2.1$ & 0,825 \\
\hline & The need for affiliation & $\mathrm{X} 2.2$ & $\mathbf{0 , 8 6 1} *$ \\
\hline & The need for power & $\mathrm{X} 2.3$ & 0,757 \\
\hline Talent Management (Y1) & Recruiting & $\mathrm{Y} 1.1$ & $\mathbf{0 , 9 0 6} *$ \\
\hline & Defence & $\mathrm{Y} 1.2$ & 0,847 \\
\hline $\begin{array}{l}\text { Employee } \\
\text { (Y2) }\end{array}$ & Develeopment & $\mathrm{Y} 1.3$ & 0,851 \\
\hline & Pride & $\mathrm{Y} 2.1$ & $\mathbf{0 , 8 6 4} *$ \\
\hline & Compliance & $\mathrm{Y} 2.2$ & 0,821 \\
\hline & Readiness & $\mathrm{Y} 2.3$ & 0,853 \\
\hline
\end{tabular}

Note: $*$ =Value loading factor largest / highest.

\subsubsection{The influence of competence on employee engagement}

Competence affects employee's engagement. The findings of this study are in line with the research conducted by Lara (2017) which states that competence affects employee's engagement in SMEs. The result of this research proves that the most influential competence characteristic is social competence, covering good behavior and good habits owned by SME employees.

\subsubsection{The influence of motivation on employee engagement}

Motivation affects employee's engagement, which means that good motivation will influence the increase of employees' attachment to the company. The findings of this study are in line with the results of Clayton's (2006), which states that motivation influences employee's engagement. The results show that the motivation of SME employees is good enough. The most influential characteristic of motivation is the characteristic of affiliation. In the SME business, the ability of employees to interact with others is necessary.

\subsubsection{The influence of talent management on employee engagement}

Talent management has an influence on employee's engagement. This means that good talent management within the company will improve the company's performance. These findings corroborate the results of previous research conducted by Bhatnagar (2007) stating that talent management influences employee's engagement in Indian companies. Other supporting studies by Bano et al. (2011) and Sadeli (2012) prove that talent management affects employee's engagement. The results found that the dominant characteristic that influences talent management is recruitment. To overcome the difficulty of getting talented people on board, SMEs usually hire part time workers. In order to improve talent management, SMEs need 
to retain talent. SMEs must use the right strategy to be able to maintain existing talent. One of the most important things in maintaining talent in SMEs is the provision of fair and competitive compensation. In addition to compensation, SMEs also seek to create a pleasant working environment to reduce talent turnover.

\subsubsection{The Influence of Competence to Talent Management}

Competence affects talent management, meaning that optimal competence can improve talent management in SMEs. The results of this study support previous research conducted by Sabuncu and Karacay (2016) which states that competence influences talent management. Research findings indicate that competence in SMEs is still not optimal and needs to be improved on a cognitive level. Increased competence can be implemented through training. In today's digital era, human resource training conducted by SMEs is more informal. For example, learning through online media and sharing information through WhatsApp and You tube.

\subsubsection{Motivational influence on talent management}

Motivation affects talent management. This means that good motivation will improve talent management in SMEs. These findings support and corroborate the results of previous research conducted by Delfgaauw (2016) who argues about the importance of talent management. Research proves that motivation affects talent management but there must be an increase, in the need for achievement.

\subsubsection{The influence of competence on employee's engagement through talent management}

The results prove the existence of the influence of competence on employee's engagement through talent management. The existence of a superior competence of employees, being cognitive, functional and social, can affect the management of talent to result in employee engagement in SMEs. Employee's engagement in this research is reflected in the aspects of pride, willingness and readiness. The factor that most affects employee's engagement is pride. This is because, being able to do the job well and on time, will affect the attachment of a person to the company where he works.

\subsubsection{The influence of motivation on employee's engagement through talent management}

This study proves the influence of Motivation to Employee Engagement through Talent Management. Field findings indicate that good motivation at work affects talent management, which in turn affects employee engagement.

\section{Conclusion}

The results of this study can be summarized as follows:

1. Competence has a direct and positive impact on employee's engagement. This means that good competence from employees can improve employee's engagement in SMEs. 
2. Motivation has a direct and positive effect on employee's engagement. The results show that the right motivation can increase employee's engagement in SMEs.

3. Talent management has a direct and positive influence on employee's engagement. Optimal talent management within the organization can influence and increase employee's engagement in SMEs.

4. Competence has a direct and positive effect on talent management. This indicates that the competencies of the employees in the organization can influence the effective of talent management in SMEs.

5. Motivation has a direct and positive effect on talent management. This shows that employee motivation to work well will improve the effectiveness of talent management in SMEs.

6. Competence directly affects employee's engagement through talent management mediation. If SME employees have optimal competencies required for business sustainability, then it will affect the effectiveness of talent management to increase employee's engagement.

7. Motivation directly affects employee's engagement through talent management mediation. This indicates that if employees in SMEs have a strong motivation to work, it will be able to affect the management of talent and cause increased employee's engagement.

This research provides theoretical implications for the development of Human Resource Management, especially in the field of employee's engagement, related to competence, motivation and talent management. Limitations of this study are as follows: 1) This study was conducted on several Tour and Travel SMEs in Malang and cannot be generalized to other organizations because of differences in organizational characteristics; 2) The instrument used in this study is a closed questionnaire and the researchers are not fully able to control the honesty and accuracy of the respondent's answer. Based on the weaknesses in this study, it can be suggested that for further research: One can examine other variables that affect employee's engagement, such as, local wisdom and knowledge management. One can develop indicators on talent management and employee's engagement. One can conduct similar research by extending the research area to test the consistency of the findings.

\section{References:}

Akram, A.A. 2014. Global Talent Management. Spinger. London.

Bano, S., Khan, M.A., Rehman, Q.H.U. \& Humayoun, A.A. 2010. Schematizing talent management: a core business issue. Far East Journal of Psychology and Business, 2(1), 4-16.

Baublyte, D. 2010 Talent management: Myth or Reality in Today's SMEs: A study into the importance and use of talent management within small and medium-sized enterprises. Vantaa, Finland: Metropolia University of Applied Sciences.

Bhatnagar, J. 2007. Talent Management Strategy of Employee Engagement in Indian ITES Employee: Key Retention. Employee Relations, Vol. 29, No. 6, 640-663. 
Clayton, G. 2006. Key skills retention and motivation: the war for talent still rages and retention is the high ground. Industrial and Commercial Training, 38(1), 37-45.

Delfgaauw, R.J. 2010. Managerial talent, motivation, and self-selection into public management. Journal of Public Economics, 94, 654-660.

Farndale, E., Pai, A., Sparrow, P. \& Scullion, H. 2014. Balancing individual and organizational goals in global talent management: A mutual-benefits perspective. Journal of World Business, 49, 204-214.

George, J. and Gareth, R.J. 2012. Understanding and Managing Organizational Behavior. Pearson Education, Inc., New Jersey.

Gibbons, J.M. 2006. Employee Engagement: A Review of Current Research and Its Implications. Conference Board.

Hwang, H. \& Takane, Y., 2004. Generalized Structured Component Analysis. Psychometrika, 69, 81-99.

Krishnan, T.N. and Scullion, H. 2017. Talent management and dynamic view of talent in small and medium enterprises. Human Resource Management, Volume 27, Issue 3, 431-441.

Lance, A.B. 2011. The Talent management: Creating a sustainable competitive advantage by selecting, developing, and promoting the best people, 2nd edition. McGraw Companies, USA.

Lara, F.J. and Salas-Vallina A. 2017. Managerial competencies, innovation and engagement in SMEs: The mediating role of organisational learning, Journal of Business Research, $79,152-160$.

Le Deist, F.D., Winterton J. and Stringfellow, E. 2006. Typology of knowledge, skills and competences: Clarification of the concept and prototype. European Centre for the Development of Vocational Training. Vol. 64, No. 3048, 1-121.

Lockwood, N. 2006. Talent Management: Driver for Organizational Success. SHRM Research Report Quarterly. https://www.shrm.org/Research/Articles/Articles/Documents/0606RQuartpdf.pdf

MacClelland, D.C. 1961. The achieving society. New York: The Free Press.

MacLeod, D. and Clarke, N. 2009. Engaging for Success: Enhancing Performance through Employee Engagement. Office of Public Sector Information, London.

Sabuncu, K.U. \& Karacay, G. 2016. Exploring Professional Competencies for Talent Management in Hospitality and Food Sector in Turkey. Procedia - Social and Behavioral Sciences 235, 443-452.

Sadeli, J. 2012. The Influence of Leadership, Talent Management, Organizational Culture and Organizational Support on Employee Engagement. International Research Journal of Business Studies, Vol. 5, Issue 3.

Scullion, H. 2011 Global Talent Management. Routledge: London.

Scullion, H. \& Collings, D. 2010. Global talent management. Abingdon: Routledge.

Thomas, C. 2007. A new measurement scale for employee engagement: scale development, pilot test, and replication. Academy of Management Proceedings, 1- 6. 